\title{
The Acute Effect of Hydrocortisone on Hepatic Glucose Output and Peripheral Glucose Utilization*
}

\author{
Frank R. Lecoce, $\dagger$ David Mebane, $\$$ and Leonard L. Madison \\ (From the Department of Internal Medicine, The University of Texas, Southwestern Medical \\ School, Dallas, Texas)
}

There is abundant experimental evidence indicating that adrenal glucocorticoids have a profound effect on carbohydrate metabolism (1-9). Agreement is general that they accelerate hepatic gluconeogenesis and increase liver glycogen stores (5-9), but their action on peripheral glucose utilization is still unsettled $(5,6,8)$. Although the effects of the chronic administration of glucocorticoids are well defined and changes in carbohydrate metabolism have been recorded as early as 2 to 4 hours (10-18) after adrenocorticoid administration, the precise time of onset of glucocorticoid-induced alterations in carbohydrate metabolism has not been established. An immediate action on glucose metabolism has not been demonstrated in vivo; indeed, recent studies have suggested that the effect of adrenocorticoids on carbohydrate metabolism is delayed for at least 2 hours, beginning at a time when steroid concentrations are decreasing $(10,13,14)$. The changes in glucose metabolism occurring in the earliest period after glucocorticoid administration are especially

* Submitted for publication July 12, 1963; accepted October 17, 1963.

This work was supported in part by a U. S. Public Health Service grant (A-4236) from the National Institute of Arthritis and Metabolic Diseases, Bethesda, Md., and by grants from the Upjohn Co., Kalamazoo, Mich., and Chas. Pfizer \& Co., New York, N. Y.

A preliminary report of this work has been published in abstract form (The paradoxical effect of hydrocortisone on hepatic glucose output. Clin. Res. 1961, 9, 29).

$\dagger$ Work done during tenure of U. S. Air Force postdoctoral fellowship. Present address: Department of Medicine, Endocrine-Renal Section, Wilford Hall, U. S. Air Force Hospital, Lackland Air Force Base, San Antonio, Texas.

$¥$ Work done during tenure of U. S. Public Health Service postdoctoral fellowship (APD-17,224) of the National Institute of Arthritis and Metabolic Diseases. Present address: Department of Surgery, The University of Texas, Southwestern Medical School, Dallas, Texas. important to define since obscuring secondary effects are less likely to be present.

The purpose of the present study was 1) to delineate the earliest detectable change in carbohydrate metabolism after acute glucocorticoid administration, 2) to characterize the early effects of glucocorticoids on hepatic glucose output, and 3 ) to determine whether glucocorticoids alter peripheral glucose utilization. Changes in hepatic glucose output and peripheral glucose utilization were followed during the initial 90 to 120 minutes after the intravenous injection of cortisol in dogs with chronic end-to-side portacaval shunts. This preparation was chosen because it separates the liver from the extrahepatic splanchnic circulation and therefore permits measurement of hepatic rather than splanchnic glucose balance. From the changes in hepatic glucose output and arterial glucose concentration, changes in peripheral glucose utilization can be calculated (19).

\section{Methods}

Thirteen studies were done on dogs with complete endto-side portacaval shunts. At least 1 month was allowed for complete recovery from the operative procedure before experiments were performed. Stable weights were maintained in these animals by a diet, supplemented with vitamins, containing $50 \%$ of the total calories as carbohydrate, 20 to $30 \%$ as protein, and the remainder as fat. Studies were performed after a 15-hour, overnight fast with Nembutal anesthesia (25 mg per $\mathrm{kg}$ ). Hepatic venous samples were collected through a cardiac catheter inserted deep into the hepatic vein under fluoroscopic control. Femoral arterial blood specimens were obtained through an indwelling Cournand needle.

In all 13 experiments hepatic glucose output was determined at 10-minute intervals for two to four control periods and then at 10 - or 15-minute intervals during the 60 - to 150-minute period of hydrocortisone infusion. Hydrocortisone was administered intravenously both as hemisuccinate and phosphate in normal saline. An average priming dose of $33 \mathrm{mg}$ of hydroçortisone (range, 0 to 50) was given and then infused at the rate of approximately $1.3 \mathrm{mg}$ per minute for the remainder of the 


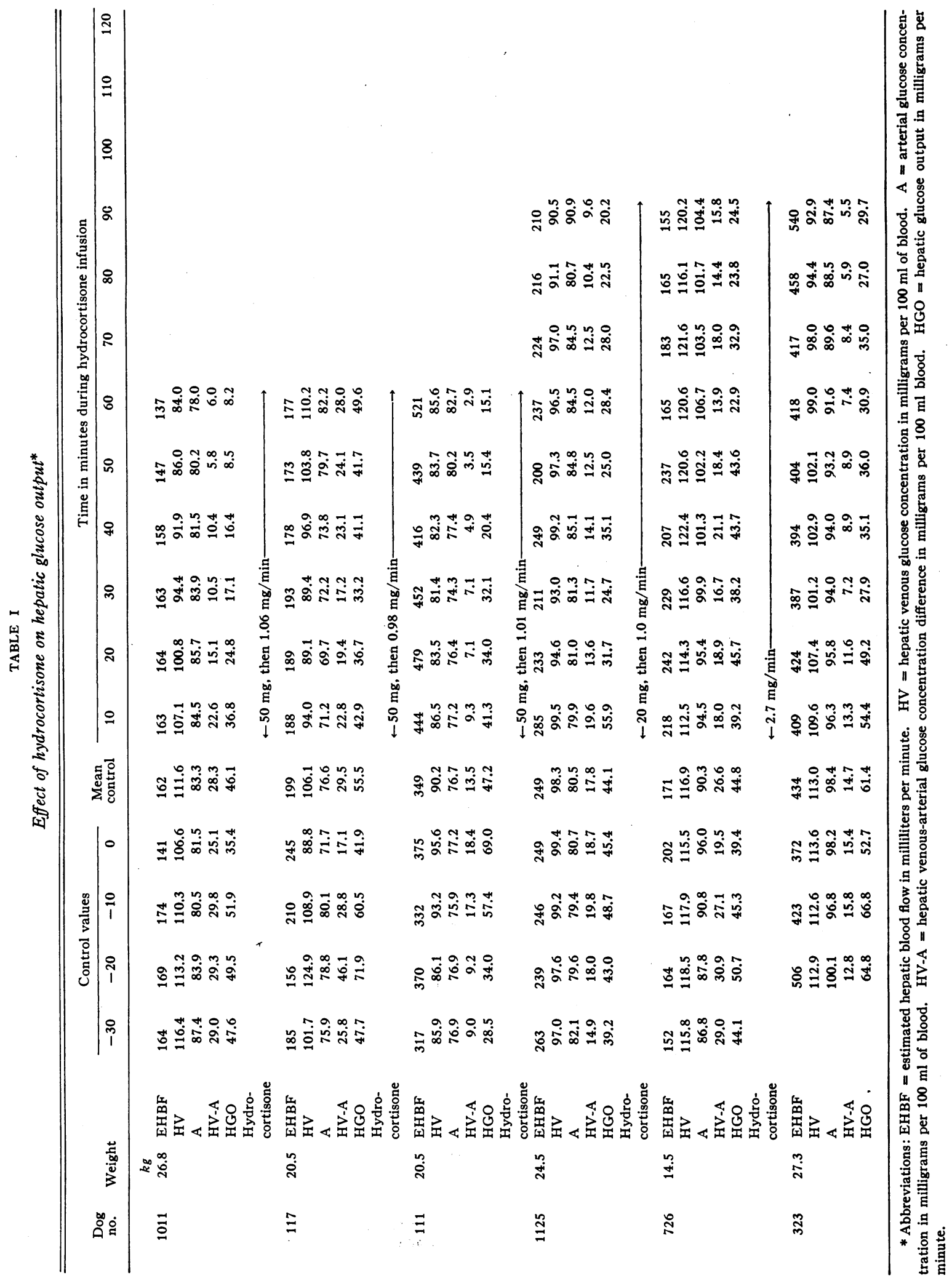


ACUTE EFFECTS OF CORTISOL ON CARBOHYDRATE METABOLISM

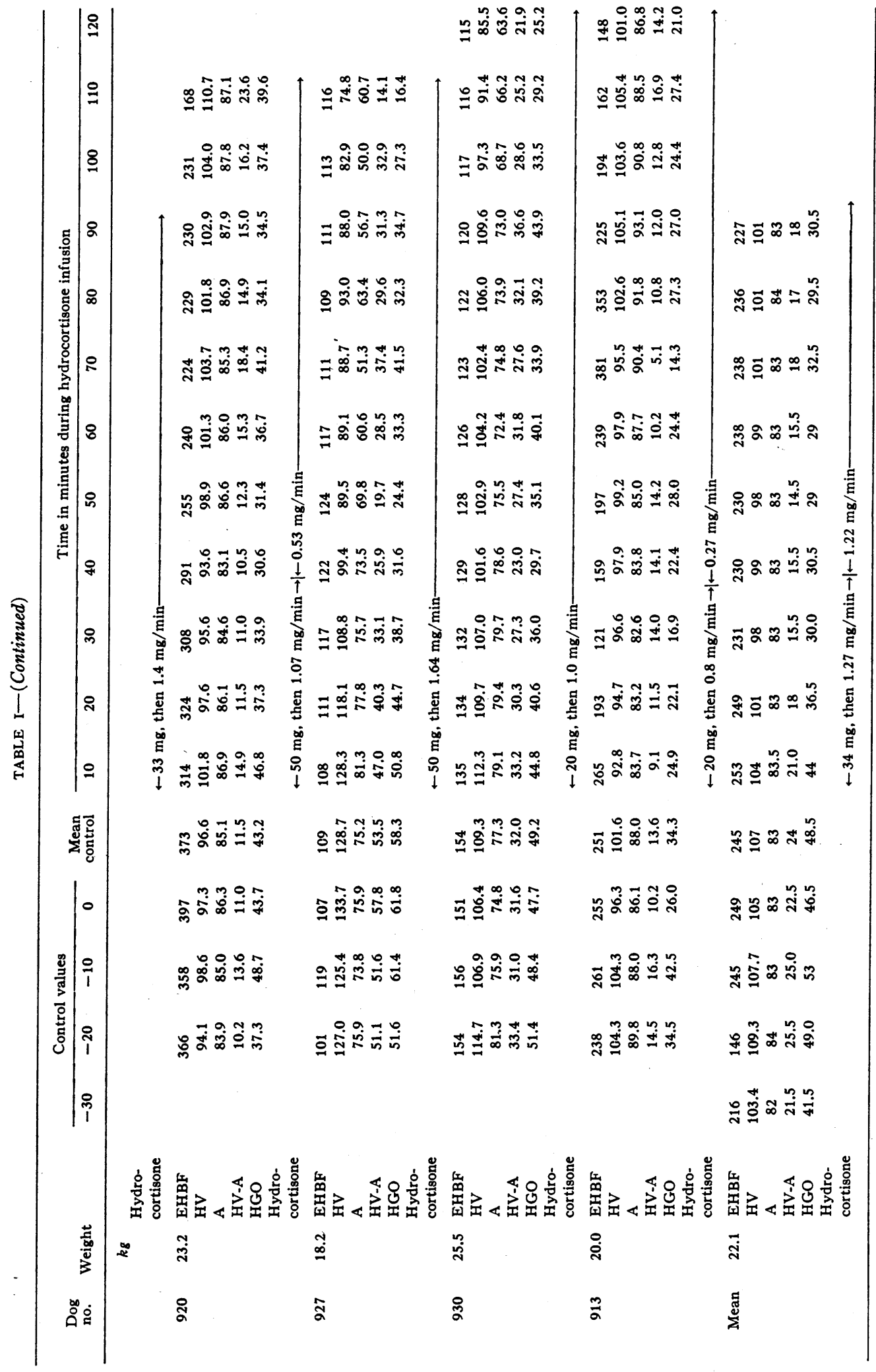




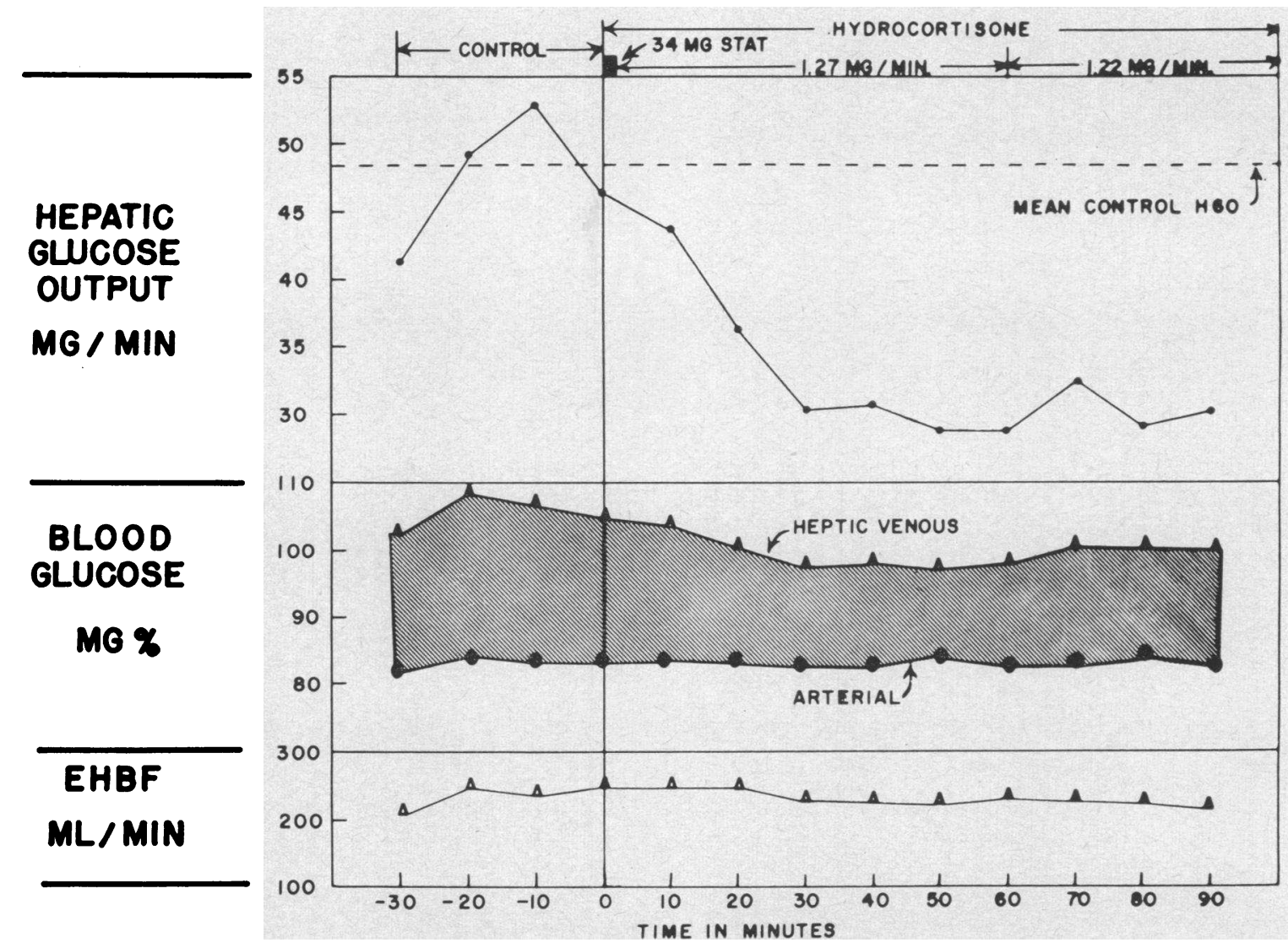

Fig. 1. Mean changes in hepatic glucose outPut dURing the aCUTE administration of cortisol. Within 20 minutes there was a significant fall in hepatic glucose output that was depressed maximally by 30 minutes and maintained at this level for the remaining hour of hydrocortisone infusion. EHBF = estimated hepatic blood flow.

TABLE II

Changes in hepatic glucose output from control during hydrocortisone infusion*

\begin{tabular}{|c|c|c|c|c|c|c|c|c|c|c|c|}
\hline \multirow{3}{*}{$\begin{array}{c}\text { Dog } \\
\text { no. }\end{array}$} & \multirow{3}{*}{$\begin{array}{l}\text { Mean } \\
\text { control }\end{array}$} & \multicolumn{10}{|c|}{ Decrease from control } \\
\hline & & \multicolumn{10}{|c|}{ Minutes after start of hydrocortisone infusion } \\
\hline & & 10 & 20 & 30 & 40 & 50 & 60 & 70 & 80 & 90 & 100 \\
\hline & & \multicolumn{10}{|c|}{$m g / m i n$} \\
\hline 1011 & 46.1 & 9.3 & 21.3 & 29.0 & 29.7 & 37.6 & 37.9 & & & & \\
\hline 117 & 55.5 & 12.6 & 18.8 & 22.3 & 14.4 & 13.8 & 5.9 & & & & \\
\hline 111 & 47.2 & 5.9 & 13.2 & 15.1 & 26.8 & 31.8 & 32.1 & & & & \\
\hline 1125 & 44.1 & +11.8 & 12.4 & 19.4 & 9.0 & 19.1 & 15.7 & 16.1 & 21.6 & 23.9 & \\
\hline 726 & 44.8 & 5.6 & +0.9 & 6.6 & 0.9 & 1.2 & 21.9 & 11.9 & 21.0 & 20.3 & \\
\hline 323 & 61.4 & 7.0 & 12.2 & 33.5 & 26.3 & 25.4 & 30.5 & 26.4 & 34.4 & 31.7 & \\
\hline 920 & 43.2 & +3.6 & 5.9 & 9.3 & 2.6 & 11.8 & 6.5 & 2.0 & 9.1 & 8.7 & 5.8 \\
\hline 927 & 58.3 & 1.5 & 13.6 & 19.6 & 26.7 & 33.9 & 25.0 & 16.8 & 26.0 & 23.6 & 21.1 \\
\hline 930 & 49.2 & 4.4 & 8.6 & 13.2 & 19.5 & 14.1 & 9.1 & 15.3 & 10.0 & 5.3 & 15.7 \\
\hline 913 & 34.3 & 10.2 & 12.1 & 17.4 & 11.9 & 6.3 & 9.9 & 20.0 & 7.0 & +3.1 & 1.7 \\
\hline Mean & 48.4 & 4.7 & 11.7 & 18.5 & 16.8 & 19.5 & 19.5 & 15.5 & 18.4 & 15.8 & 11.1 \\
\hline$p$ & & $>0.1$ & $<0.03$ & $<0.001$ & $<0.001$ & $<0.005$ & $<0.005$ & $<0.005$ & $<0.010$ & $<0.050$ & \\
\hline
\end{tabular}

$*+$ represents an increase in hepatic glucose output. 
TABLE III

Comparison of the effect of hydrocortisone infusion on hepatic release of new (unlabeled) glucose and hepatic glucose output*

\begin{tabular}{|c|c|c|c|c|c|c|c|c|c|c|c|c|c|}
\hline \multirow{2}{*}{$\begin{array}{l}\text { Dog } \\
\text { no. }\end{array}$} & \multirow[b]{2}{*}{ Weight } & & \multicolumn{4}{|c|}{ Control values } & \multirow{2}{*}{$\begin{array}{c}\text { Mean } \\
\text { control }\end{array}$} & \multicolumn{6}{|c|}{ Time in minutes during hydrocortisone infusion } \\
\hline & & & -30 & -20 & -10 & 0 & & 15 & 30 & 45 & 60 & 75 & 90 \\
\hline $\begin{array}{r}317 \\
.\end{array}$ & $\begin{array}{c}k g \\
20.5\end{array}$ & $\begin{array}{l}\text { EHBF } \\
\text { HV } \\
\text { A } \\
\text { HV-A } \\
\text { HGO } \\
\text { HRNG } \\
\text { Hydro- } \\
\text { cortisone }\end{array}$ & $\begin{array}{c}198 \\
109.5 \\
80.2 \\
29.3 \\
58.0 \\
61.0\end{array}$ & $\begin{array}{r}241 \\
96.8 \\
79.4 \\
17.4 \\
41.9 \\
34.3\end{array}$ & $\begin{array}{r}235 \\
94.2 \\
76.6 \\
17.6 \\
41.4 \\
41.8\end{array}$ & $\begin{array}{r}187 \\
91.6 \\
74.4 \\
17.2 \\
32.2 \\
36.8\end{array}$ & $\begin{array}{c}215 \\
98.0 \\
77.7 \\
20.3 \\
43.4 \\
43.5\end{array}$ & $\begin{array}{r}176 \\
91.3 \\
73.9 \\
17.4 \\
30.6 \\
31.6 \\
\end{array}$ & $\begin{array}{r}212 \\
82.4 \\
70.5 \\
11.9 \\
25.2 \\
24.0 \\
-33 \mathrm{~m}\end{array}$ & $\begin{array}{r}216 \\
81.3 \\
71.6 \\
9.7 \\
21.0 \\
23.6 \\
\\
\text { g, then }\end{array}$ & $\begin{array}{c}248 \\
78.3 \\
70.8 \\
7.5 \\
18.6 \\
18.6 \\
1.3 \mathrm{mg} /\end{array}$ & $\begin{array}{r}238 \\
79.7 \\
73.3 \\
6.4 \\
15.2 \\
16.2 \\
\text { min } \\
\end{array}$ & $\begin{array}{r}258 \\
88.8 \\
79.2 \\
9.6 \\
24.8 \\
28.0 \\
\end{array}$ \\
\hline 46 & 20.0 & $\begin{array}{l}\text { EHBF } \\
\text { HV } \\
\text { A } \\
\text { HV-A } \\
\text { HGO } \\
\text { HRNG } \\
\text { Hydro- } \\
\text { cortisone }\end{array}$ & $\begin{array}{c}268 \\
93.4 \\
74.7 \\
18.7 \\
50.1 \\
51.3\end{array}$ & $\begin{array}{c}276 \\
95.6 \\
74.5 \\
21.1 \\
58.2 \\
58.6\end{array}$ & $\begin{array}{r}302 \\
97.2 \\
76.7 \\
20.5 \\
61.9 \\
70.6\end{array}$ & $\begin{array}{r}263 \\
103.5 \\
80.8 \\
22.7 \\
59.7 \\
64.7\end{array}$ & $\begin{array}{r}277 \\
97.4 \\
76.7 \\
20.7 \\
57.5 \\
61.3\end{array}$ & $\begin{array}{r}288 \\
111.4 \\
84.1 \\
27.3 \\
78.6 \\
78.3 \\
\end{array}$ & $\begin{array}{r}258 \\
96.7 \\
82.4 \\
14.3 \\
36.9 \\
39.1 \\
-33 \mathrm{~m}\end{array}$ & $\begin{array}{r}271 \\
91.2 \\
81.3 \\
9.9 \\
26.8 \\
31.1 \\
\\
\text { Ig, then }\end{array}$ & $\begin{array}{r}303 \\
87.9 \\
78.9 \\
9.0 \\
27.3 \\
31.1 \\
0.8 \mathrm{mg} /\end{array}$ & $\begin{array}{r}286 \\
85.7 \\
79.9 \\
5.8 \\
16.6 \\
20.8 \\
\text { min } \\
\end{array}$ & $\begin{array}{r}282 \\
85.2 \\
75.8 \\
9.4 \\
26.5 \\
26.9 \\
\end{array}$ \\
\hline 314 & 25.0 & $\begin{array}{l}\text { EHBF } \\
\text { HV } \\
\text { A } \\
\text { HV-A } \\
\text { HGO } \\
\text { HRNG } \\
\text { Hydro- } \\
\text { cortisone }\end{array}$ & & $\begin{array}{r}217 \\
105.5 \\
78.6 \\
26.9 \\
58.4 \\
61.8\end{array}$ & & $\begin{array}{c}241 \\
100.2 \\
75.8 \\
24.4 \\
58.8 \\
55.9\end{array}$ & $\begin{array}{c}229 \\
102.8 \\
77.2 \\
25.7 \\
58.6 \\
58.9\end{array}$ & $\begin{array}{c}203 \\
93.5 \\
70.5 \\
23.0 \\
46.7 \\
51.5 \\
\end{array}$ & $\begin{array}{r}210 \\
81.5 \\
66.5 \\
15.0 \\
31.5 \\
31.3 \\
-33 \mathrm{~m}\end{array}$ & $\begin{array}{c}209 \\
81.2 \\
65.4 \\
15.8 \\
33.0 \\
36.7 \\
\\
\text {, then }\end{array}$ & $\begin{array}{c}238 \\
78.0 \\
64.3 \\
13.7 \\
32.6 \\
30.4 \\
1.3 \mathrm{mg} /\end{array}$ & $\begin{array}{r}234 \\
74.8 \\
63.2 \\
11.6 \\
27.1 \\
25.1 \\
\min \\
\end{array}$ & $\begin{array}{r}226 \\
73.5 \\
61.5 \\
12.0 \\
27.1 \\
27.0\end{array}$ \\
\hline Mean & 21.8 & $\begin{array}{l}\text { EHBF } \\
\text { HV } \\
\text { A } \\
\text { HV-A } \\
\text { HGO } \\
\text { HRNG } \\
\text { Hydro- } \\
\text { cortisone }\end{array}$ & $\begin{array}{r}236 \\
101.5 \\
77.5 \\
24.0 \\
54.0 \\
56.2\end{array}$ & $\begin{array}{r}245 \\
99.3 \\
77.8 \\
21.5 \\
50.4 \\
51.6\end{array}$ & $\begin{array}{r}268 \\
95.7 \\
76.6 \\
19.1 \\
51.6 \\
56.2\end{array}$ & $\begin{array}{r}230 \\
98.4 \\
77.0 \\
21.4 \\
50.2 \\
52.5\end{array}$ & $\begin{array}{r}240 \\
99.4 \\
77.2 \\
22.2 \\
53.2 \\
54.6\end{array}$ & $\begin{array}{r}222 \\
98.7 \\
76.2 \\
22.6 \\
52.0 \\
53.8 \\
\end{array}$ & $\begin{array}{r}227 \\
86.9 \\
73.1 \\
13.7 \\
31.2 \\
31.5 \\
-33 \mathrm{~m}\end{array}$ & $\begin{array}{r}232 \\
84.6 \\
72.8 \\
11.8 \\
26.9 \\
30.5 \\
\text { g, then }\end{array}$ & $\begin{array}{r}263 \\
81.4 \\
71.3 \\
10.1 \\
26.2 \\
26.7 \\
1.1 \mathrm{mg}\end{array}$ & $\begin{array}{r}253 \\
80.1 \\
72.1 \\
7.9 \\
19.6 \\
20.7 \\
\text { min }\end{array}$ & $\begin{array}{r}255 \\
82.5 \\
76.2 \\
10.3 \\
26.1 \\
27.3\end{array}$ \\
\hline
\end{tabular}

* Abbreviations: $\mathrm{EHBF}=$ estimated hepatic blood flow in milliliters per minute. $\mathrm{HV}=$ hepatic venous glucose concentration in milligrams per $100 \mathrm{ml}$ of blood. $A=$ arterial glucose concentration in milligrams per $100 \mathrm{ml}$ of blood. $\mathrm{HV}-\mathrm{A}=$ hepatic venous-arterial glucose concentration difference in milligrams per $100 \mathrm{ml}$ of blood. HGO = hepatic glucose output in milligrams per minute. HRNG = hepatic release of new glucose in milligrams per minute.

study. Estimated hepatic blood flow (EHBF) was estimated by the clearance and extraction method of Bradley, Ingelfinger, Bradley, and Curry (20) using $\mathrm{I}^{121}$-labeled Rose Bengal as the extractable material (21). Blood glucose concentration was determined in triplicate on each sample by the Somogyi copper iodometric technique (22). Hepatic glucose output (HGO) in milligrams per minute at each interval was calculated as the product of the estimated hepatic blood flow and the hepatic venous-arterial glucose concentration difference (HV-A). The clinical methods and statistical analysis used in this report have been described in detail in a previous publication from this laboratory (19).

In three additional experiments hepatic output of glucose was measured simultaneously by determining the balance of glucose across the liver as in the initial 10 experiments and by determining changes in the specific activity of blood glucose across the liver (23) from the following formula: $\mathrm{G}_{\mathrm{R}}=\mathrm{G}_{\mathrm{T}}\left(1-\mathrm{HV}_{\mathbf{s \Delta}} / \mathrm{A}_{\mathbf{s \Delta}}\right)$, where $H_{V_{\mathbf{S A}}}=$ specific activity of hepatic venous glucose, $A_{\mathbf{S A}}=$ specific activity of arterial glucose, $G_{R}=$ amount of unlabeled glucose released from the liver in milligrams per minute, and $G_{T}=$ total amount of glucose in milligrams per minute leaving the liver, calculated as the product of hepatic venous glucose concentration and hepatic blood flow. In these experiments, uniformly labeled $\mathrm{C}^{14}$ glucose was administered by the primer-infusion technique (24). Specific activity of hepatic venous and arterial blood glucose was determined in a liquid scintillation spectrometer after isolating the blood glucose as potassium gluconate according to the technique of Blair and Segal (25) modified for liquid scintillation counting. 
TABLE IV

Effect of hydrocortisone infusion on peripheral glucose utilization

\begin{tabular}{|c|c|c|c|c|c|c|c|c|c|c|}
\hline \multirow[b]{2}{*}{$\begin{array}{l}\text { Dog } \\
\text { no. }\end{array}$} & \multirow[b]{2}{*}{ Weight } & \multirow[b]{2}{*}{$\begin{array}{c}\text { Estimated } \\
\text { glucose } \\
\text { space }\end{array}$} & \multicolumn{3}{|c|}{ Glucose pool } & \multicolumn{3}{|c|}{ Hepatic glucose output } & \multirow{2}{*}{$\begin{array}{l}\text { Change in } \\
\text { glucose pool } \\
\text { attributable } \\
\text { to change } \\
\text { in HGO† }\end{array}$} & \multirow{2}{*}{$\begin{array}{l}\text { Calculated } \\
\text { change in } \\
\text { peripheral } \\
\text { glucose } \\
\text { utilization }\end{array}$} \\
\hline & & & $\begin{array}{c}\text { Initial } \\
\text { size }\end{array}$ & $\begin{array}{l}\text { Size at } \\
60 \mathrm{~min}\end{array}$ & Change* & $\underset{\text { control }}{\text { Mean }}$ & $\begin{array}{l}\text { Mean } \\
\text { during } \\
60 \text { min }\end{array}$ & Change & & \\
\hline & $\mathrm{kg}$ & $L$ & & $m g$ & & & $m g / m f n$ & & & $m g / h r$ \\
\hline 1011 & 26.8 & 8.04 & 6,697 & 6,271 & -426 & 46.1 & 22.6 & $\downarrow 23.5$ & $-1,410$ & -984 \\
\hline 117 & 20.5 & 6.15 & 4,711 & 5,055 & +344 & 55.5 & 43.0 & $\downarrow 12.5$ & -750 & $-1,094$ \\
\hline 111 & 20.5 & 6.15 & 4,717 & 5,086 & +369 & 47.2 & 29.4 & $\downarrow 17.8$ & $-1,068$ & $-1,437$ \\
\hline 1125 & 24.5 & 7.35 & 5,917 & 6,211 & +294 & 44.1 & 35.0 & $\downarrow 9.1$ & -546 & -840 \\
\hline 726 & 14.5 & 4.35 & 3,928 & 4,641 & +713 & 44.8 & 39.7 & $\downarrow 5.1$ & -306 & $-1,019$ \\
\hline 920 & 23.2 & 6.96 & 5,923 & 5,986 & +63 & 43.2 & 37.1 & $\downarrow 6.1$ & -366 & -429 \\
\hline 927 & 18.2 & 5.46 & 4,106 & 3,309 & -797 & 58.3 & 40.3 & $\downarrow 18.0$ & $-1,080$ & -283 \\
\hline 930 & 25.5 & 7.65 & 5,913 & 5,538 & -375 & 49.2 & 39.4 & $\downarrow 9.8$ & $-\quad 594$ & -220 \\
\hline 913 & 20.0 & 6.00 & 5,280 & 5,262 & -18 & 34.3 & 24.7 & $\downarrow 9.6$ & $-\quad 576$ & -558 \\
\hline 317 & 20.5 & 6.15 & 4,779 & 4,354 & -425 & 43.4 & 27.8 & $\downarrow 15.6$ & -936 & -511 \\
\hline 46 & 20.0 & 6.00 & 4,602 & 4,734 & +132 & 57.5 & 45.4 & $\downarrow 12.1$ & -726 & -858 \\
\hline 323 & 27.3 & 8.19 & 8,059 & 7,502 & -557 & 61.4 & 42.1 & $\downarrow 19.3$ & $-1,158$ & -601 \\
\hline 314 & 25.0 & 7.50 & 5,790 & 4,823 & -977 & 58.6 & 40.5 & $\downarrow 18.1$ & $-1,086$ & -109 \\
\hline Mean & 22.0 & 6.61 & 5,417 & 5,290 & -128 & 49.5 & 35.9 & $\downarrow 13.6$ & -816 & -688 \\
\hline
\end{tabular}

* + denotes increase ; - denotes decrease.

\section{Results}

Effect on hepatic glucose output. In each experiment hydrocortisone infusion resulted in a rapid decline in hepatic glucose output (Table I). Mean hepatic glucose output decreased significantly (Table II) from the control value of 48.5 $\mathrm{mg}$ per minute to $36.5 \mathrm{mg}$ per minute within 20 minutes after starting the hydrocortisone infusion and averaged $30 \mathrm{mg}$ per minute during the next 70 minutes. This $38 \%$ depression in the hepatic output of glucose persisted for the remainder of the hydrocortisone infusion (Figure 1). The change in hepatic glucose output was in large part attributable to a $30 \%$ decrease in mean hepatic venous-arterial glucose concentration difference, which fell from $24 \mathrm{mg}$ per $100 \mathrm{ml}$ during the control period to $16.6 \mathrm{mg}$ per $100 \mathrm{ml}$ during the 20 - to 90 -minute period after starting the hydrocortisone. In one study (dog 726, Table I) a priming dose of hydrocortisone was not administered, and hepatic glucose output did not fall until 60 minutes after the start of a constant hydrocortisone infusion.

The decrease in hepatic glucose output determined by measuring the balance of glucose across the liver was paralleled by a decline in the release of endogenously produced glucose by the liver (Table III). Hepatic release of new (isotopically unlabeled) glucose fell $24.1 \mathrm{mg}$ per minute from a mean control of 54.6 to $30.5 \mathrm{mg}$ per minute by 30 minutes. Hepatic output of glucose declined a similar amount, $26.3 \mathrm{mg}$ per minute, from the mean control of 53.2 to $26.9 \mathrm{mg}$ per minute during the same period of time.

The close correspondence between changes in the hepatic glucose output determined by measuring the balance of glucose across the liver and by following the changes in specific activity of blood glucose across the liver attests to the validity of the isotopic technic, but only under circumstance where the liver is not extracting and retaining large quantities of glucose from the perfusing blood (26).

Effect on peripheral glucose utilization. Approximations of the rate of peripheral glucose utilization were made from the data listed in Tables I and III (19). A glucose space of $30 \%$ of the body weight of the $\operatorname{dog}(4,19,27)$ was assumed, and the glucose pool was calculated before and after 1 hour of hydrocortisone infusion. The calculations show that an inhibition in the rate of peripheral glucose utilization occurred in each of the 13 studies during the initial 60 minutes after starting hydrocortisone (Table IV). This decrease in peripheral glucose utilization, which averaged $688 \mathrm{mg}$ during the first hour after starting the hydrocortisone infusion, cannot be ascribed to a decreased delivery of glucose to the peripheral tissues consequent to the reduction in hepatic glucose output, since it persisted in the 
five studies in which blood glucose concentration rose (Tables I and III) during the initial 60 minutes.

Although mean arterial glucose concentration was unchanged (Figure 1), it fell in seven and rose in five studies during the first hour. The ensuing level of the arterial glucose concentration after hydrocortisone is the result of the magnitude of the depression in hepatic glucose output in relation to the inhibition of peripheral glucose utilization. An unchanging arterial glucose concentration belies the profound alterations in carbohydrate metabolism that are occurring.

\section{Discussion}

These data show that two significant alterations in carbohydrate metabolism occur within $20 \mathrm{~min}$ utes after starting a hydrocortisone infusion in the fasted dog. Not only was hepatic glucose output significantly diminished, but this was accompanied by an inhibition of peripheral glucose utilization (Tables I and IV). The simultaneous inhibition of peripheral glucose utilization and fall in hepatic glucose output resulted in an unchanged mean arterial glucose concentration. The hazards of interpreting data based solely on observations of changes in arterial glucose concentration are obvious, since such observations would not have detected the profound alterations in glucose metabolism that occurred acutely during hydrocortisone administration.

Because of the experimental evidence indicating that prolonged glucocorticoid administration increases gluconeogenesis $(1,3,5,6,9)$ and hepatic glucose production (4), the acute fall in hepatic glucose output found in these studies seems paradoxical and requires explanation. $\mathrm{A}$ fall in hepatic glucose output may be the result of a decrease in gluconeogenesis, a decrease in glycogenolysis, an increase in glycogenesis, or any combination thereof. Since previous studies have shown that both an acceleration of gluconeogenesis $(8,9,28)$ and an increase in hepatic glycogen stores (28-32) occur within several hours after glucocorticoid administration, it seems unlikely that decreased gluconeogenesis could account for the fall in hepatic glucose output found in these studies. The combination of a decrease in hepatic glucose output noted in these studies and the early rise in liver glycogen reported by others (28-32) is best explained by either a decrease in hepatic phosphorylase or an increase in glycogen synthetase activity, or both, thereby diverting to glycogen glucose previously destined to leave the liver and maintain hepatic glucose output. No significant decrease in total hepatic phosphorylase activity after cortisol administration has been reported. In fact, most studies show an increased activity $(33,34)$ occurring as early as $12^{\circ}$ hours after steroid administration (32). Although Steiner, Rauda, and Williams found an increase in mean glycogen synthetase activity from 2.4 to 3.7 $\mu$ moles per $\mathrm{g}$ of liver per hour within 5 hours after prednisolone injection in rats, they did not consider this rise significant (35). In recent studies, however, Hilz, Tarnowski, and Arend (36) reported an early increase in hepatic synthetase activity, the consequence of a rapid increase in glucose- 6 -phosphate concentration that rises considerably within 30 minutes after glucocorticoid administration. Not only is the activity of the enzyme increased early by the cortisol-induced increase in activator glucose-6-phosphate concentration, but within 6 hours an actual increase in enzyme protein is also very likely present (36). Possibly the early cortisol-induced stimulation of gluconeogenesis is too small to be easily measured or to increase hepatic glucose output but large enough to increase the glucose-6-phosphate pool, activate glycogen synthetase, and thereby decrease hepatic glucose output.

Apparently the decrease in the output of glucose by the liver that attends the acute administration of cortisol is the consequence of the shunting of glucose produced within the liver to glycogen. In these studies hepatic glucose output averaged $30 \mathrm{mg}$ per minute (Table I) from 30 to 90 minutes after starting the cortisol infusion. Since mean control hepatic glucose output was $48.5 \mathrm{mg}$ per minute, the liver was conserving and very likely shunting to glycogen $18.5 \mathrm{mg}$ of glucose per minute or approximately $1 \mathrm{~g}$ per hour. The changes in hepatic glucose metabolism and hepatic glucose output postulated to occur immediately after glucocorticoids are contrasted in Figure 2 with those thought to occur with more prolonged administration.

The data from the present studies afford un- 


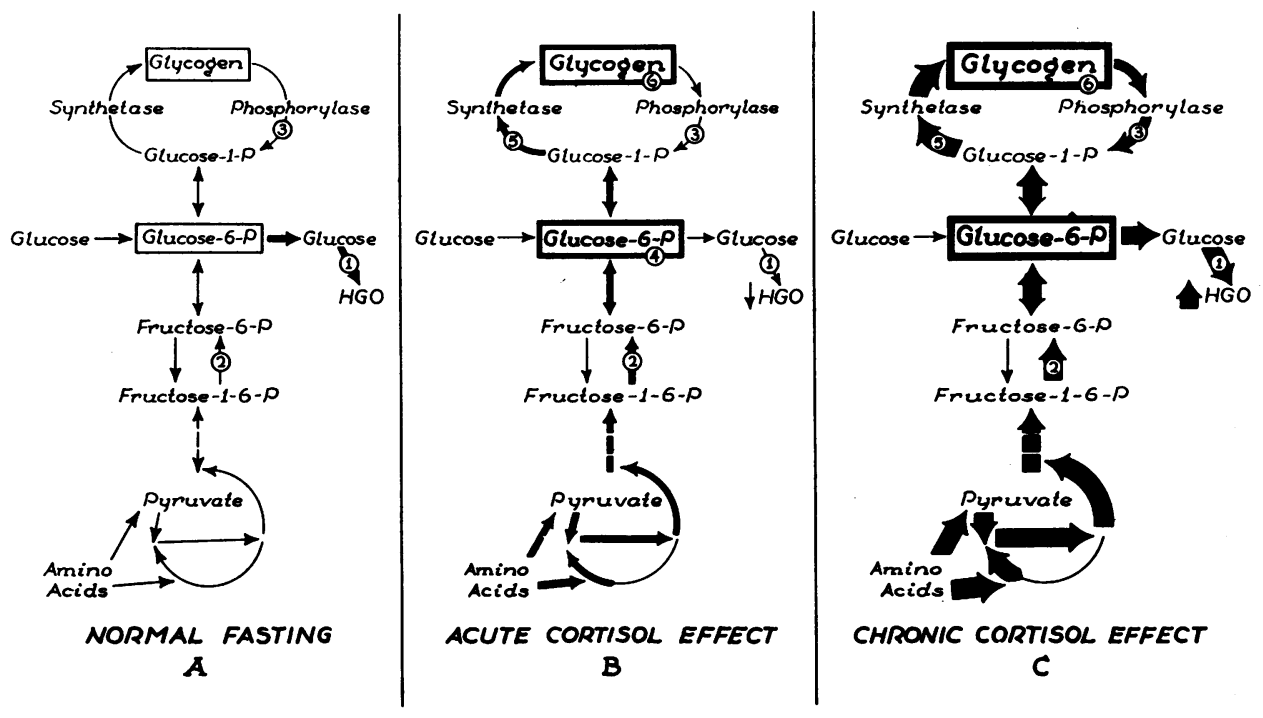

Fig. 2. Comparison of the effects of the acute and chronic administration of gLUCocorticoids on hepatic glucose metabolism and output. Panel A describes the conditions during the postabsorptive state when hepatic glucose output (1) is maintained via gluconeogenesis (2) and glycogenolysis (3). The acute administration of cortisol (panel B), probably by producing a small increase in gluconeogenesis (2), increases glucose-6-phosphate concentration (4), which stimulates glycogen synthetase activity (5) and diverts endogenously produced glucose to glycogen (6), thereby resulting in a reduction in hepatic glucose output (1). Prolonged adrenocorticoid administration (panel $\mathrm{C}$ ) results in an increased hepatic glucose output (1) and glycogen stores (6) despite increased phosphorylase activity (3), probably as a consequence of a greater stimulation of synthetase activity (5) coupled with a marked augmentation of gluconeogenesis (2).

equivocal evidence for an immediate inhibitory effect of glucocorticoids on peripheral glucose utilization, an action still being debated $(5,6,8$, 28). Many investigators have reported indirect evidence for an inhibition of peripheral glucose utilization by a variety of technics $(1,8,15,30$, $37-40)$. Despite all these data, De Bodo and Altszuler in a recent critical review (6) concluded that there was no definitive evidence for an inhibition of peripheral glucose utilization by adrenocorticol steroids and suggested that they may indirectly enhance glucose utilization. Thorn, Renold, and Cahill (5) also seriously questioned the occurrence of a glucocorticoid-induced depression of peripheral glucose utilization and pointed out that the discrepancy between the increase in glucose stores and urinary nitrogen excretion may be explainable on mechanisms other than decreased metabolism of glucose by the extrahepatic tissues.

The results of our studies leave little room for doubt that hydrocortisone causes an inhibition of peripheral glucose utilization that is acute in onset and significant in amount. Moreover, this inhibition was underestimated in our experiments. Peripheral glucose utilization as calculated in these studies includes glucose metabolized by all the extrahepatic tissues including the central nervous system. Since the brain utilizes about $50 \%$ of the splanchnic glucose output in the postabsorptive state (41) and since the rate of glucose utilization by the brain does not change during glucocorticoid administration (42), the decline in utilization of the extracerebral peripheral tissues must have been even greater than our calculations indicate. The data from the present studies, however, give no insight into the biochemical mechanism responsible for this immediate inhibition of peripheral glucose utilization. This inhibition of peripheral glucose utilization cannot be attributed to an increase in plasma nonesterified fatty acids (NEFA) as postulated by Randle, Garland, Hales, and Newsholme (43), since arterial plasma NEFA concentrations did not change during the acute infusions of hydro- 
cortisone in the present studies. Recent in vitro investigations suggest that glucocorticoids depress the phosphorylation of glucose to glucose-6-phosphate and thereby decrease glucose utilization by muscle (39), heart (40), and adipose tissue (44).

\section{Summary}

Thirteen experiments were performed on dogs with complete end-to-side portacaval shunts to determine whether hydrocortisone acutely altered hepatic glucose balance and peripheral glucose utilization. Dogs with chronic end-to-side portacaval shunts were selected, since in this preparation the liver is completely separated from the extrahepatic splanchnic bed, allowing the measurement of glucose balance across the liver alone rather than across the entire splanchnic circulation.

Hydrocortisone infusion had an immediate effect on carbohydrate metabolism, producing both a prompt reduction in hepatic glucose output and a decrease in peripheral glucose utilization. The glucose output by the liver declined progressively and decreased about 38\% from control values within 30 minutes after starting hydrocortisone administration. A quantitatively similar decline in peripheral glucose utilization occurred during the same time period. These changes persisted over the entire 90-minute period of hydrocortisone infusion.

\section{References}

1. Long, C. N. H., B. Katzin, and E. G. Fry. The adrenal cortex and carbohydrate metabolism. Endocrinology 1940, 26, 309.

2. Abelove, W. A., and K. E. Paschkis. Comparison of the diabetogenic action of cortisone and growth hormone in different species. Endocrinology 1954, $55,637$.

3. Welt, I. D., D. Stetten, Jr., D. J. Ingle, and E. H. Morley. Effect of cortisone upon rates of glucose production and oxidation in the rat. J. biol. Chem. 1952, 197, 57.

4. Altszuler, N., R. Steele, J. S. Wall, and R. C. pe Bodo. Effects of adrenocortical steroids on carbohydrate metabolism in hypophysectomized dogs; studies with $C^{14}$-labeled glucose. Amer. J. Physiol. 1957, 191, 29.

5. Thorn, G. W., A. E. Renold, and G. F. Cahill, Jr. The adrenal and diabetes. Some interactions and interrelations. Diabetes 1959, 8, 337.
6. De Bodo, R. C., and N. Altszuler. Insulin hypersensitivity and physiological insulin antagonists. Physiol. Rev. 1958, 38, 389.

7. Ingle, D. J. Experimental steroid diabetes. Diabetes 1958, 5, 187.

8. Long, C. N. H., O. K. Smith, and E. G. Fry. Actions of cortisol and related compounds on carbohydrate and protein metabolism in Metabolic Effects Of Adrenal Hormones. Boston, Little, Brown, 1960, p. 4.

9. Ashmore, J. The role of adrenal steroids in the regulation of hepatic metabolism in Metabolic Effects of Adrenal Hormones, Boston, Little, Brown, 1960, p. 25.

10. West, K. M. Response of the blood glucose to glucocorticoids in man. Determination of the hyperglycemic potencies of glucocorticoids. Diabetes 1959, 8, 22.

11. Perkoff, G. T., R. Hahn, H. Kent, C. A. Nugent, and F. H. Tyler. A delayed effect of adrenalcortical steroids on blood glucose levels and disappearance rates. Clin. Res. 1960, 8, 143.

12. Frawley, T. F. The role of the adrenal cortex in glucose and pyruvic acid metabolism in man including the use of intravenous hydrocortisone in acute hypoglycemia. Ann. N. Y. Acad. Sci. 1955, 61, 464.

13. Glenn, E. M., R. O. Stafford, S. C. Lyster, and B. J. Bowman. Relation between biological activity of hydrocortisone analogues and their rate of inactivation by rat liver enzyme systems. Endocrinology 1957, 61, 128.

14. Hyde, P. M. Liver glycogen deposition after intravenous and intragastric administration of cortisol4-C $\mathrm{C}^{14}$ to rats. Endocrinology 1957, 61, 774.

15. Kupperman, H. S., M. Persky, J. Linsk, M. Isaacs, and M. Rosenbluth. The paradoxical effect of intravenous hydrocortisone upon carbohydrate metabolism. Ann. N. Y. Acad. Sci. 1955, 61, 494.

16. Papper, S., L. Saxon, T. E. Prout, and H. C. Alpert. The effects of cortisone on the fructose and glucose tolerance tests of normal men. J. Lab. clin. Med. 1956, 48, 13.

17. Duncan, L. Cortisone-induced impairment of glucose tolerance in the detection of diabetic diathesis. Quart. J. exp. Physiol. 1956, 41, 85.

18. Froesch, E. R., A. I. Winegrad, A. E. Renold, and G. W. Thorn. Mechanism of the glucosuria produced by the administration of steroids with glucocorticoid activity. J. clin. Invest. 1958, 37, 524.

19. Madison, L. L., B. Combes, R. Adams, and W. Strickland. The physiological significance of the secretion of endogenous insulin into the portal circulation. III. Evidence for a direct immediate effect of insulin on the balance of glucose across the liver. J. clin. Invest. 1960, 39, 507.

20. Bradley, S. E., F. J. Ingelfinger, G. P. Bradley, and J. J. Curry. The estimation of hepatic blood flow in man. J. clin. Invest. 1945, 24, 890. 
21. Combes, B. Estimation of hepatic blood flow in man and in dogs by $\mathrm{I}^{131}$-labeled rose bengal. Simultaneous comparison with the sulfobromophthalein sodium. J. Lab. clin. Med. 1960, 56, 537.

22. Somogyi, M. Determination of blood sugar. J. biol. Chem. 1945, 160, 69.

23. Schambye, P., and F. Tarding. Changes induced by insulin and tolbutamide in the glucose output of the liver. Ann. N. Y. Acad. Sci. 1959, 74, 557.

24. De Bodo, R. C., N. Altszuler, A. Dunn, R. Steele, D. T. Armstrong, and J. S. Bishop. Effects of exogenous and endogenous insulin on glucose utilization and production. Ann. N. Y. Acad. Sci. 1959, 82, 431.

25. Blair, A., and S. Segal. The isolation of blood glucose as potassium gluconate. J. Lab. clin. Med. $1960,55,959$.

26. Madison, L. L., D. Mebane, F. Lecocq, and B. Combes. Physiological significance of the secretion of endogenous insulin into the portal circulation. V. The quantitative importance of the liver in the disposition of glucose loads. Diabetes 1963, $12,8$.

27. Searle, G. L., E. H. Strisower, and I. L. Chaikoff. Glucose pool and glucose space in the normal and diabetic dog. Amer. J. Physiol. 1954, 176, 190.

28. Renold, A. E., and J. Ashmore. Metabolic effects of adrenal corticosteroids in Diabetes, R. H. Williams, Ed. New York, Paul B. Hoeber, 1960, p. 194.

29. Ashmore, J., F. Stricker, W. C. Love, and G. Kilsheimer. Cortisol stimulation of glycogen synthesis in fasted rats. Endocrinology 1961, 68, 599.

30. Glenn, E. M., B. J. Bowman, R. B. Bayer, and C. R. Meyer. Hydrocortisone and some of its effects on intermediary metabolism. I. In vivo studies. Endocrinology 1961, 68, 386.

31. Dorsey, J. L., and A. Munck. Studies on the mode of action of glucocorticoids in rats: a comparison of the effects of cortisol and glucose on the formation of liver glycogen. Endocrinology 62, 71, 605.

32. Eisenstein, A. B. Effect of cortisol on liver phosphorylase activity. Proc. Soc. exp. Biol. (N. Y.) 1962, 109, 839.
33. Willmer, J. S. Changes in hepatic enzyme leve's after adrenalectomy. I. Phosphorylase, phosphoglucomutase and phosphoglucoseisomerase. Canad. J. Biochem. 1960, 38, 1095.

34. Hunter, N. W., and C. E. Johnson. The effects of hydrocortisone on glycogen storage and phosphorylase activity of frog liver. Cell and comp. Physiol. 1960, 55, 275.

35. Steiner, D. F., V. Rauda, and R. H. Williams. Effects of insulin, glucagon, and glucocorticoids upon hepatic glycogen synthesis from uridine diphosphate glucose. J. biol. Chem. 1961, 236, 299.

36. Hilz, H., W. Tarnowski, and P. Arend. Glucose polymerisation and cortisol. Biochem. biophys. Res. Commun. 1963, 10, 492.

37. Russell, J. A. Adrenal and hypophysis in carbohydrate metabolism of the eviscerated rat. Amer. J. Physiol. 1943, 140, 98.

38. Boutwell, R. K., and R. Chiang. The acute effect of cortisone treatment on the utilization of glucose by the mouse. Arch. Biochem. 1954, 50, 461.

39. Riddick, F. A., Jr., R. M. Reisler, and D. M. Kipnis. The sugar transport system in striated muscle: effect of growth hormone, hydrocortisone and alloxan diabetes. Diabetes 1962, 11, 171.

40. Morgan, H. E., M. J. Henderson, D. M. Regen, and C. R. Park. Regulation of glucose uptake in heart muscle from normal and alloxan-diabetic rats: the effects of insulin, growth hormone, cortisone, and anoxia. Ann. N. Y. Acad. Sci. 1959, 82, 387.

41. Myers, J. D. Net splanchnic glucose production in normal man and in various disease states. $\mathrm{J}$. clin. Invest. 1950, 29, 1421.

42. Sensenbach, W., L. L. Madison, and L. Ochs. The effect of ACTH and cortisone on cerebral flood flow and metabolism. J. clin. Invest. 1953, 32, 372.

43. Randle, P. J., P. B. Garland, C. N. Hales, and E. A. Newsholme. The glucose fatty-acid cycle. Its role in insulin sensitivity and metabolic disturbances of diabetes mellitus. Lancet 1963, 1, 785.

44. Leboeuf, B., A. E. Renold, and G. F. Cahill, Jr. Studies on rat adipose tissue in vitro. IX. Further effects of cortisol on glucose metabolism. J. biol. Chem. 1962, 237, 988. 